\title{
Morphometric evaluation of foramen magnum
}

\author{
Vidya $\mathrm{H} \mathrm{K}^{1}$, Nagashree $\mathrm{M} \mathrm{V}^{2 *}$ \\ ${ }^{1}$ Assistant Professor, Department of Anatomy, Shridevi Institution Of Medical Sciences And Research Hospital, Sira Road, Tumkur-572106, \\ INDIA. \\ ${ }^{2}$ Associate Professor, Department of Anatomy, KVG Medical College and Hospital, Sullia - 574327, INDIA. \\ Email: vidyassmc@gmail.com, drnagashreegireesh@gmail.com
}

$\underline{\text { Abstract }}$

Background and Aim: Foramen magnum is an important landmark in the posterior part of the skull base, vital structures pass through it. Those structures may suffer compression in cases of foramen magnum achondroplasia and foramen magnum brain herniation. The knowledge of foramen magnum diameters are needed to determine some malformaitons sucha as Arnold chiari syndrome, which shows expansion of transverse diameter. The purpose of this study was to evaluate the measurements of foramen magnum and to calculate area and index of foramen magnum. Materials and Methods: The present study was carried out on 134 dry skull bones, the diameters of foramen magnum were measured using digital vernier calipers and its Area and Index were calculated. Results: The mean anteroposterior diameter of foramen magnum was $34.56 \mathrm{~mm}$ in males and $32.7 \mathrm{~mm}$ in females. The mean transverse diameter of foramen magnum was $28.95 \mathrm{~mm}$ in males and $27.57 \mathrm{~mm}$ in females. The mean foramen magnum index was 84.07 and mean area of foramen magnum was $762.01 \mathrm{~mm}^{2}$. Conclusion: Results of the present study may be useful for neurosurgeons in analyzing morphological anatomy of craniovertebral junction for transcondylar approach in brainstem lesions. Since mean anteroposterior diameter, transverse diameter and area of foramen magnum were more in males compared to females hence it may be use full in sex determination of human skull in forensic analysis and anthropology studies.

Key Words: Foramen magnum, morphmetric evaluation, skull base, sex determianiton.

*Address for Correspondence:

Dr. Nagashree M V, Associate Professor, Department of Anatomy, KVG Medical College and Hospital, Sullia - 574327, INDIA.

Email: drnagashreegireesh@gmail.com

Received Date: 03/08/2018 Revised Date: 14/09/2018 Accepted Date: 06/10/2018

DOI: https://doi.org/10.26611/1001811

\begin{tabular}{|l|l|}
\hline \multicolumn{2}{|c|}{ Access this article online } \\
\hline Quick Response Code: & Website: \\
www.medpulse.in \\
\hline
\end{tabular}

\section{INTRODUCTION}

The complexity of the base of the skull makes this study useful for surgeons and radiologists. The foramen magnum is a large opening in the base of skull which provides a wide communication between the posterior cranialfossa and vertebral canal. The lower end of the medulla oblongata, vertebral artery and spinal accessory nerve pass through it ${ }^{1}$. The dimensions of the foramen magnum are clinically as well as surgically important because these vital structures passing through it may be compressed in cases of foramen magnum herniation, meningiomas and achondroplasis ${ }^{2}$. The knowledge of foramen magnum diameters is needed to determine some malformaitons such Arnold chiari syndrome which shows expansion of transverse diameter. In neurosurgical practice the transcondylar approach is commonly used to access the lesions which are ventral to the brain stem and cervicomedullar junction. It was reported that understanding boney anatomy of condylar region is important for this approach ${ }^{4}$. Gender determination in unindentified skeletons is not an easy task especially in war fare, explosions and other mass disasters, identification may be complicated because of skeletal fragmentation ${ }^{5}$. The dimensions of the foramen magnum are greater in male cranium compared with female cranium hence foramen magnum dimensions can be used to determine sex in medicolegal conditions and disasters where other bones were fragmented ${ }^{6}$. It has been noted that the cranial base remains intact in cases where the rest of the cranium has been compromised thus the researchers have made use of this fact by analyzing sexually significant dimorphic trait for this anatomical region ${ }^{5,7}$.

\section{MATERIALS AND METHOD}

In the present study 134 dry human skulls (91 Male, 43 Female) in the department of Anatomy Shridevi institute of medical sciences and research hospital Tumkur were examined. The bones which were eroded and deformed 
were excluded from the study, all other adult skull bones which were in good condition were included. Sex of each skull was determined by classic anatomic features, and the following parameters were recorded.

a) The anteroposterior diameter was measured in millimeters $(\mathrm{mm})$ from the end of anterior border (Basion) to the end of posterior border (Opisthion) (Figure-1).

b) The transverse diameter was measured in millimeters $(\mathrm{mm})$ from point of maximum concavity on the right margin to the maximum concavity on the left margin. (Figure-1),

c) Area of the foramen magnum was calculated using Randinsky formula ${ }^{8}$. Foramen magnum area $=1 / 4$ X 3.14 X FML X FMWFML- Foramen magnum length(Anteroposterior diameter)
FMW-Foramen magnum width.(Transverse diameter)

d) Foramen magnum index (FMI) was calculated by formula FMI = FMW X 100/FML. The results were expressed as mean, range, \pm standard deviation (SD).

\section{RESULTS}

In the present study 134 dry human skull bones were examined, among 13491 were male and 43 were female skull bones. The mean value of FMW was $28.5 \mathrm{~mm}$, FML was $34.0 \mathrm{~mm}$, FMI was 84.07 and area of foramen magnum was $762.01 \mathrm{~mm}^{2}$. The measurements comparing between male and female skulls were tabulated in table 1 . The foramen magnum transverse diameter, longitudinal diameter and foramen magnum area in male skulls were more compared with the foramen magnum measurements in female skull bones as represented in Figure 2.

Table 1: Showing the range, mean, and standard deviation (SD) for Dimensions of foramen magnum in male and female skull

\begin{tabular}{ccccccc}
\hline \multirow{2}{*}{ Parameters } & \multicolumn{3}{c}{ Male } & \multicolumn{3}{c}{ Female } \\
\cline { 2 - 6 } & Range & Mean & SD & Range & Mean & SD \\
\hline FML $(\mathrm{mm})$ & $29.5-39.6$ & 34.56 & \pm 2.04 & $29.0-36.5$ & 32.71 & \pm 1.98 \\
FM W $(\mathrm{mm})$ & $24.5-33.6$ & 28.95 & \pm 2.10 & $23.0-31.5$ & 27.57 & \pm 2.03 \\
AREA $\left(\mathrm{mm}^{2}\right)$ & $581.26-1036.57$ & 786.96 & \pm 88.25 & $543.67-879.63$ & 709.21 & \pm 84.43 \\
FMI & $69.61-100.6$ & 83.89 & \pm 5.984 & $67.44-101.96$ & 78.17 & \pm 6.57
\end{tabular}

Table 2: Comparison of the anteroposterior and transverse diameters of the foramen magnum, in different studies

\begin{tabular}{|c|c|c|c|}
\hline Author / Ethnicity & Gender & FML in $\mathrm{mm}$ & FM W in $\mathrm{mm}$ \\
\hline Sayee R. et al & Male & 34.2 & 28.5 \\
\hline Karnataka $(1987)^{9}$ & Female & 33.5 & 28.0 \\
\hline M uralidhar P Shepur & Male & 33.4 & 28.5 \\
\hline Karnataka $(2014)^{10}$ & Female & 33.1 & 27.3 \\
\hline Routal RR et al & Male & 35.5 & 30.6 \\
\hline Gujarati $(1984)^{11}$ & Female & 32.0 & 27.1 \\
\hline Sauzo Gil et al & Male & 36.5 & 30.6 \\
\hline Brazilian $(2009)^{12}$ & Female & 35.6 & 29.5 \\
\hline Cataliana Herrera et al & Male & 36.5 & 31.1 \\
\hline Spain white skulls(1987) ${ }^{13}$ & Female & 34.3 & 29.6 \\
\hline Gapert et al & Male & 35.9 & 30.51 \\
\hline British $(2008)^{14}$ & Female & 34.7 & 29.36 \\
\hline Arpan Dubay et al & Male & 33.4 & 28.5 \\
\hline M adhyapradesh $(2017)^{15}$ & Female & 33.1 & 27.3 \\
\hline P.Devadas et al & Male & 36.7 & 29.7 \\
\hline Telangana $(2017)^{16}$ & Female & 32.1 & 26.1 \\
\hline \multirow{2}{*}{ Present Study } & Male & 34.56 & 28.9 \\
\hline & Female & 32.7 & 27.5 \\
\hline
\end{tabular}

Table 3: Comparison of Area and Index of foramen magnum in various studies

\begin{tabular}{ccc}
\hline Author $/$ Year & Foramen magnum area $\left(\mathrm{mm}^{2}\right)$ mean & Foramen magnum index(mean) \\
\hline Gunay et al $(2000)^{6}$ & 909.91 & - \\
Burdan et al $(2012)^{17}$ & 877.4 & 89.34 \\
Jain et al $(2014)^{18}$ & - & 86.69 \\
Shikha Sharma etal $(2015)^{19}$ & 970.57 & 87.68 \\
Present study & 762.01 & 84.07 \\
\hline
\end{tabular}




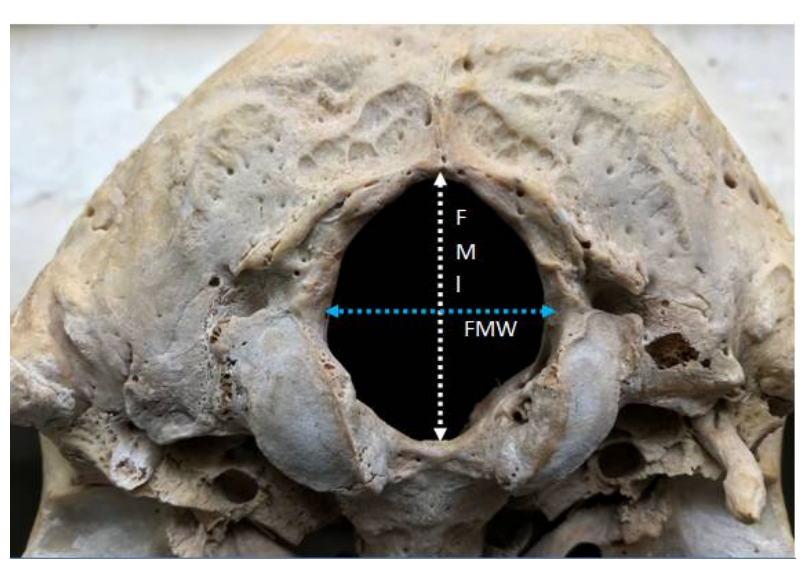

Figure 1

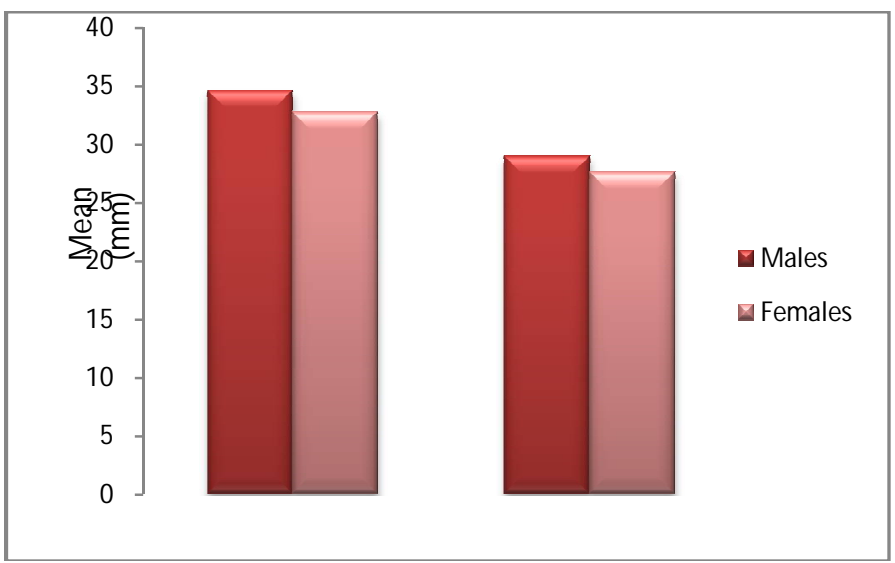

Figure 2

Figure 1: M easurements of Foramen magnum length (FML) and Foramen magnum width (FMW)

Figure 2: Graph showing transverse diameter and longitudinal diameters of foramen magnum in male and female skull

\section{DISCUSSION}

The results of the present study were compared with the other studies on different ethnicity in Table -2 and Table - 3. In the present study all the parameters of foramen magnum FML, FMW, FMI and area of foramen magnum had sexual dimorphism but in study conducted by muralidhar $\mathrm{p}$ shepur et $a l^{10}$, Arpan Dubay et $a l^{14}$ does not show much difference in FML. The surface area of the foramen magnum in the present study were $786.96 \mathrm{~mm}^{2}$ and $709.21 \mathrm{~mm}^{2}$ in male cranium and female cranium respectively which was lower than the Spanish population, Telangana population and Turkish population study. In Telangana population $1089.99 \mathrm{~mm}^{2}$ in males, and $837.81 \mathrm{~mm}^{2}$ in females ${ }^{16}$. In Turkish population $909.9 \mathrm{~mm}^{2}$ in males and $819.01 \mathrm{~mm}^{2}$ in females ${ }^{2}$ and in Spanish population $888.4 \mathrm{~mm}^{2}$ in males and $801.0 \mathrm{~mm}^{2}$ in females $^{13}$. Whereas the area of foramen magnum in Iraq population was lower than the present study it was $765.2 \mathrm{~mm}^{2}$ in males and $670 \mathrm{~mm}^{2}$ in females ${ }^{20}$. Thus the morphometry of foramen magnum shows sexual dimorphism and ethnic variance.

\section{CONCLUSION}

In the present study all the parameters of foramen magnum recorded showed sexual dimorphism, which may help in sex determination of the human skull with other parameters of the skulls in forensic analysis and anthropological studies. Results of the study may also be useful in neurosurgeons and radiologists in surgeries and in determining radiological malformation of this region.

\section{REFERENCES}

1. Standarding S. Gray's anatomy. The anatomical bais of clinical practice. 39th ed. London: Elsevier Churchill Livingstone; 2005:460.

2. Murshed K A, Cicekeibasi A E, Tuncer I. Morphometric evaluation of the foramen magnum and variations in its shape. A study of computerized tomographic images of normal adults. Tur J Med Sci 2003; 33:301-306.

3. Sgouros S, Goldin HJ, Hockely AD, Wake MJ, et al. Intracranial volume change in child hood. J Neurosurg. 1999; 91:610-616.

4. Muthukumar N, Swaminathan R, Venkatesh G, Bhanumathy SP. A morphometric analysis of foramen magnum region as it relates to the transcondylar approach. ActNeurochir (Wien) 2055; 147:889-895.

5. Holland TD. Sex determination of fragmentary crania by analysis of crania base. Am J Phys. Anthropol. 1986; 70:203-208.

6. Gunay Y. and Altinkok M. The value of the size of foramen magnum in sex determination. Journal of Clinical Forensic Medicine. 2000; 7:147-149.

7. Graw M. Morphometrische and Morphognostiische Geschlectsdiagnostik an der menschlichen Schadelbasis in:oehmicen M, Geserick G(eds) Ostiologische identification and Altersschatzung Schmidt - toomhild, Lubeck, 2001:103-121.

8. Radiansky L. Relative brain size a new measure. Science. 1967; 155:836-838.

9. Sayee R, Jankiram S, Thomas IM. Foramen magnum measurements of crania from Karnataka. J Anat Soc India 1987; 36(2):87-89.

10. Muralidhar P Shepur, Magi M, Nanjundappa B, Pavan P Havaldar, Premalatha Gogi, Shaik Hussain Saheb. Morphometric analysis of foramen magnum. Int $\mathbf{J}$ Anat Res 2014; 2(1):249-55.

11. Routal RR., Pal GP., Bhagwat SS. et al. Metrical studies with sexual dimorphism in foramen magnum of human crania. Journal of the Anatomical Society of India. 1984; 2(33):85-89.

12. Sauzo, G.I. Russo, P.P, Zavando, M.D.A, Smith, R.L. Sexual dimorphism in the foramen magnum dimensions. Int. j. Morphol. 2009; 27(1):21-23.

13. Herrera CJC. Study of the anatomic metric values of the foramen magnum and its relation to sex. Acta Anatomica. 1987; 130:344-347.

14. Gapert R, Black S and Last J: sex determination from magnum: discriminant function analysis in an eighteenth 
and nineteenth century British sample. Int $\mathrm{j}$ Legal Med. 2008; 123(1):25-23.

15. Arpan Dubey, S K Verma. The anatomy of occipital condyles and foramen magnum and their surgical importance: A morphometric study. Int J Anat Res 2017; 5(2.1): 3780-83

16. P Devadas, M Janardhan Rao, M Yesender, B H Shiny Vinila. Study on the morphometric analysis of the foramen magnum as an indicator for sex determination. Int J Anat Res 2017; 5(3.1):4163-4167.

17. F Burdan, J Szumi O, J.Walocha, L.Klepacz, B.Madej, Czekajska -Chehab, A. Drop. Morphology of the foramen magnum in young Eastern European adults. Folia Morphol,2012;71(4):205-216.
18. JainD, Jasuja O P, Nath S. Evaluation of foramen magnum in sex determination from human crania by using discriminant function analysis. E1 mednifco journal 2014; 2(2):89-96.

19. Ahikha Sharma, Anil Kumar Sharma, Bhawani Shankar Modi, Mohd. Arshad. Morphometric evaluation of the foramen magnum and variation in its shape and size: A study on human dried skull. Int J Anat Res 2015; 3(3):1399-1403.

20. AT Uthman, NH Al-Rawi and JF Al-Timimi. Evaluation of foramen magnum in gender determination using helical CT scanning. Dentomaxillofacial Radiology 2012; 41:197-202.

Source of Support: None Declared
Conflict of Interest: None Declared

